\title{
London and the Making of Provincial Literature
}




\section{MATERIAL TEXTS}

Series Editors

$$
\begin{array}{cc}
\text { Roger Chartier } & \text { Leah Price } \\
\text { Joseph Farrell } & \text { Peter Stallybrass } \\
\text { Anthony Grafton } & \text { Michael F. Suarez, S.J. }
\end{array}
$$




\title{
London and the Making of Provincial Literature
}

\author{
Aesthetics and \\ the Transatlantic Book Trade, \\ I800-I850
}

\section{Joseph Rezek}

\section{$\overline{\text { PENN }}$}


Copyright (C) 2015 University of Pennsylvania Press

All rights reserved. Except for brief quotations used for purposes of review or scholarly citation, none of this book may be reproduced in any form by any means without written permission from the publisher.

\author{
Published by \\ University of Pennsylvania Press \\ Philadelphia, Pennsylvania I9IO4-4II2 \\ www.upenn.edu/pennpress
}

Printed in the United States of America on acid-free paper

$$
\begin{array}{llllllllll}
\text { I } & 3 & 5 & 7 & 9 & \text { IO } & 8 & 6 & 4 & 2
\end{array}
$$

Library of Congress Cataloging-in-Publication Data Rezek, Joseph, author.

London and the making of provincial literature : aesthetics and the transatlantic book trade, I80o-I850 / Joseph Rezek.

pages $\mathrm{cm}$.- (Material texts)

Includes bibliographical references and index.

ISBN 978-0-8I22-4734-3 (alk. paper)

I. English fiction-I9th century-History and criticism. 2. Book industries and trade-England-London-History-I9th century. 3. Book industries and trade-United States-History-I9th century. 4. American fictionI9th century-History and criticism. 5. Irish fiction-19th century-History and criticism. 6. Scottish fictionI9th century-History and criticism. 5. Irish fiction-19th century-History and criticism. 6. Scottish fiction-I9th century-History and criticism. 7. English fiction-Irish authors-I9th century-History and criticism. 8. English fiction-Scottish authors-roth century-History and criticism. 9. National characteristics in literature. Io. Nationalism in literature. II. Literature-Aesthetics. I. Title. II. Series: Material texts. PR86I.R4820I5 $820.9^{\prime} 007-\mathrm{dc} 23$ 2015005986 
To my enthusiastic parents, Geoff and Jackie Rezek 
This page intentionally left blank 